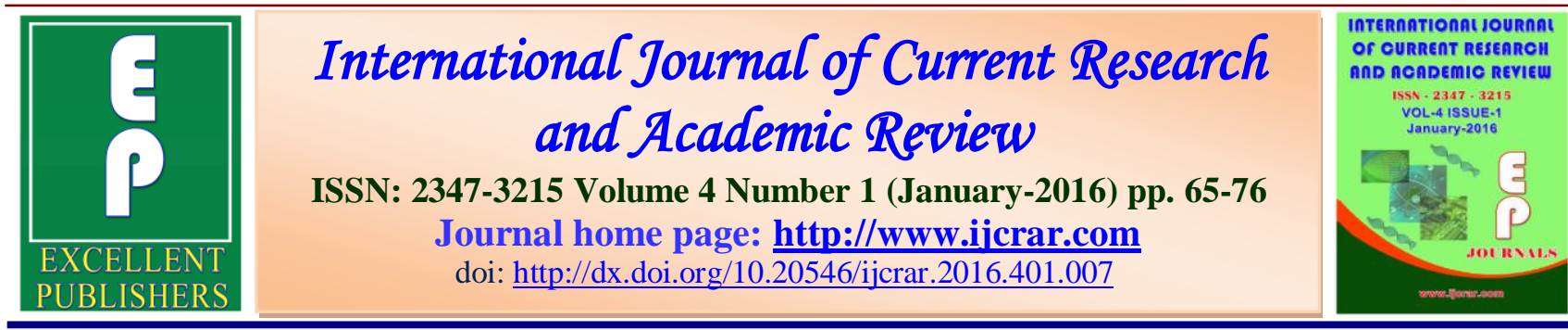

\title{
Assessment of Cardiac Cost of Two Age Groups of Brick Carriers During Summer in Different Unorganized Brick making Sector in West Bengal, India
}

\section{Santi Gopal Maity and Subhashis Sahu*}

Ergonomics and Occupational Physiology Laboratory, Department of Physiology, University of Kalyani, Kalyani, West Bengal, India

*Corresponding author

\begin{tabular}{|c|c|}
\hline KEYWORDS & A B S T R A C T \\
\hline $\begin{array}{l}\text { Brick carriers, } \\
\text { Cardiac cost, } \\
\text { Net CC, } \\
\text { Relative CC, } \\
\text { Extremely } \\
\text { heavy work }\end{array}$ & $\begin{array}{l}\text { In brick making industry, brick carrying activity requires extreme physical } \\
\text { efforts and imposes additional load on cardiovascular system of the workers } \\
\text { in hot environment. Lack of data about age associated alteration of cardiac } \\
\text { cost among the brick carriers impinged us for this study. The purpose of this } \\
\text { study was to assess the cardiac cost of two age groups of brick carriers in } \\
\text { summer seasons. } 156 \text { brick carriers, having minimum one years experiences, } \\
\text { were divided into two groups i.e., younger carriers and older carriers. } \\
\text { Anthropometric parameters along with different cardiac indices were } \\
\text { calculated with Polar Heart-Rate Monitor. The wet bulb globe temperature } \\
\text { (WBGT out) index of the worksite was also measured. Group-wise comparison } \\
\text { of cardiac indices and effect of age on those indices were performed using 't'- } \\
\text { test and correlation coefficients respectively adjusting for confounders. All } \\
\text { cardiac parameters were positively correlated with one another except for } \\
\text { average working HR with PREC, Relative CC and Net CC; Working HR max } \\
\text { with PREC and Relative CC; and SRHB with Relative CC. It was seen that } \\
\text { the brick carriers surpassed the recommended limits of cardiac strain indices } \\
\text { like Net CC and Relative CC, especially with increasing age. This indicates } \\
\text { the job used to "heavy" to "extremely heavy" in accordance with the cardiac } \\
\text { parameters. }\end{array}$ \\
\hline
\end{tabular}

\section{Introduction}

Brick is a very important building material for a developing country, like India. The majority of new buildings use bricks, and construction is the symbol of improvement in the urban sector. However, the reality is that people, who work with this rough material, will hardly, able to beneficial of boom. Manual brick manufacturing units of India employ millions of labourers (Government of India, 
2006). Brick manufacturing and its ancillary trades involve mostly unorganized and unregulated jobs. With the expansion of the construction work, the demand for bricks is growing by leaps and bound. Notwithstanding the advancement of technologies, brick-manufacturing units in West Bengal are still performed manually, especially in the unorganized sectors (Sett and Sahu, 2008). The attentions towards health and safety aspects of these labourers are relatively poor compared to that of the organized sectors (Snook and Ciriello, 1991).

The enticement of steady work draws migrant labour families from villages of the same and other states coming to these brickmaking units temporarily or on contractual basis for a period of about 8 months. In this working period, (October to May) they work very hard in spite of adverse working environmental situations like humidity, dust, sun, heating surface of the furnace chamber, etc. These were cause in summer seasons for the increment of cardiac cost with the increase of work load among the brick carriers as well as other brick field workers.

There are different working activities in the brick field. Brick carrying is one of the most important activities. The brick carrier earn money based on the number of bricks they carrying, which encourages them to work from dawn till dusk and try to carry brick as many as possible on their head, with speedily walking in the rough surface of the field as well as in the furnace chamber. Those increased their physiological stress as well as work load day to day and this might affect on their cardiovascular system.

Brick carrying required extensive skill and physical effort, and also job type is heavy in nature. So a continuous and speedily performed job can create heavy work load to the carriers and it increases more in summer seasons because of increasing environmental temperature and humidity (Azer and McNall, 1972; Hancock and Vasmatzidis, 2003). The heat exposure caused dehydration in the worker working outside (Pitts et al., 1994; Coyle, 2004). In West Bengal, average environmental temperature during summer seasons ranges between $28^{\circ} \mathrm{C}-44^{\circ} \mathrm{C}$, specifically April and May are the hottest months.

In Indian context, a majority of work associated physiological studies have focused on jobs that are characteristically dynamic, arduous in nature and performed in outdoor. In the last few decades, many such studies have been conducted on determination of physical workload and heat exposure on various occupations, such as stone cutting (Ramanamurthy and Dakhyani, 1962) unskilled building construction jobs (Sensarma et al., 1975), inland fishing (Biswas and Samanta, 2005 and 2006), mining (Saha et al., 2007 and 2010) agriculture work (Nag and Dutta, 1980) and vanrickshawpullar (Sahu et al., 2012).

But so far there has been no published study on the physiological cost of work of male brick carriers of different age groups in a hot environment. So, this study was mainly aimed at assessing cardiac cost as well as cardiovascular work load and the effect of aging of brick carriers working at a high ambient temperature.

\section{Materials and Methods}

\section{Participants}

The study group consisted of 156 male brick carriers aged 18-55 years, with at least one years of working experience in this occupation. They were randomly selected as participants and divided into two groups depending on their age i.e. younger carrier (YC, $\mathrm{n}=98)$ and older carrier (OC, $\mathrm{n}=58)$. 
The mean $(S D)$ age of one group of participants was 28.05 (6.05) years (range: 18-40) and 48.85 (4.08) years (range: 41$55)$ of the other.

\section{Study Period and Task Design}

This study was done in summer season (March-May) from9:00 to 11:00, between carrier's working periods. For the first 1.5hour, they were acquainted with the study and some data were collected about the job, Physical profile, resting heart rate (HR), etc. Next, the brick carriers were asked to perform the experimental task, i.e., to carry the bricks for $30 \mathrm{~min}$. Here, all the brick carriers carrying 8-12 bricks on their head.

\section{Physical Profile}

Body height and weight were measured with a standardized anthropometric rod and properly calibrated weighing machine, respectively. From those data, body mass index (BMI) and body surface area (BSA) were calculated with Weisell's (2002) and Banerjee and Sen's (1955) methods, respectively.

\section{Physiological Parameters}

\section{Resting, Working and Partial Recovery HR}

HR was constantly controlled with a monitor (Polar Accurex Plus, Polar Electro Oy, S810i, Finland). Resting HR was measured before the participants performed their task. Working HR was recorded every minute up to 30 min of work, and partial recovery HR was recorded up to 20 min after cessation of work.

\section{Predicted Maximal HR}

Predicted maximal HR of the participants was calculated from their respective ages with Londeree and Moeschberger's equation (1982):
$\mathrm{HR}_{\max }=206.3-(0.711 \times$ Age $)$

where HRmax = predicted maximal HR.(1)

\section{Average Working HR}

Average working HR was derived from the value of the fourth minute of work onwards (Nag et al., 1979).

\section{Percentage of Reserve HR}

Percentage of reserved HR for average working HR and working maximal HR was calculatedfrom predicted maximal $\mathrm{HR}$ for respective ages:

$\%$ of reserved $\mathrm{HR}$ for $\mathrm{X}=\left[\left(\mathrm{HR}_{\max }-\mathrm{X}\right)\right.$ / $\left.\mathrm{HR}_{\max }\right] \mathrm{x} 100 \%(2)$

where $X$ = average working HR or working maximal HR $\left(H R_{\max }\right)$.

\section{Cardiac Strain}

Net and relative cardiac cost (CC) was considered as two derived indices of cardiac strain(Costa et al., 1989); they were determined with Equations A\& B:

A) net $\mathrm{CC}=$ sum of working heart beats(resting $\mathrm{HR}) \times$ working time, $(3)$

B) relative $\mathrm{CC}=$ net $\mathrm{CC} /[$ (working $\mathrm{HRmax}$ - resting $\mathrm{HR}) \times$ working time] $\times 100 \%(4)$

whereCC $=$ cardiac cost, $\mathrm{HR}=$ heart rate, $\mathrm{HR} \max =$ working maximal HR.

\section{Work Strain or Sum of Recovery Heart Beats (SRHB)}

SRHB is a measure of work strain, which was calculated by summating the values of HR during the partial recovery period of 20 min for eachparticipant. 


\section{Percentage of Recovery (PREC)}

PREC was calculated from Pradhan, Thakur, Mukherjee, et al.'s equation; it is expressed as the ratio of fall in HR during the recovery period as a percentage of the increment of working over resting HR(Pradhan et al., 2004):

PREC $=[(a-b) /(a-c)] \times 100 \%$

Where PREC $=$ percentage of recovery, $\mathrm{a}=$ HR of last minute of work, $b=\mathrm{HR}$ of last minute of recovery recorded, $\mathrm{c}=$ resting HR.

\section{Thermal Environment}

Dry bulb temperature, natural wet bulb temperature and globe temperature were recorded hourly during study periods with dry bulb, wet bulb and globe thermometers. Next, the wet bulb globe temperature index in outdoor conditions was calculated with Equation(Parsons, 1993):

WBGTout $=0.7 \mathrm{nWBT}+0.2 \mathrm{GT}+0.1 \mathrm{DBT}$ (6)

whereWBGTout $=$ wet bulb globe temperature index in outdoor conditions, nWBT $=$ natural wet bulb temperature, $\mathrm{GT}=$ global temperature, DBT $=$ dry bulb temperature; all in degrees Celsius.

\section{Statistical Analysis}

Means and standard deviations were calculated for the physical and physiological parameters. Unpaired Student's $t$ test for unequal sample size between groups was performed to analyze the differences in the physical characteristics of the participants (age, height, weight, BMI, BSA); work experience and physiological parameters, including cardiac strain parameters. Correlation analysis was also performed among physiological parameters to find the degree of their interdependence. Levels of significance were taken as $p<.001, p<.01$, and $p<.05$ (Das and Das, 2004).

\section{Results and Discussion}

Brick carrying is physiologically demanding task. Brick carriers are engaged in this strenuous job throughout their eight month period of working session. In India as well as in west Bengal summer seasons are at its peak form March to June. Maximum air temperature touches 40 to $48^{\circ} \mathrm{C}$. This environmental condition is not suitable for the heavy work.

The study was conducted in summer seasons, in study period (9 a.m-11a.m) average WBGT $_{\text {out }}$ index was recorded 30.49 $\pm 1.137^{\circ} \mathrm{C}$. According to Dey et al., (2007) and the guidelines proposed by WHO (1969) and ACGIH (1992) for WBGT index, value more than $25^{\circ} \mathrm{C}$ is stressful. This will definitely bound to add an extra stress to the cardiovascular system as well as to increase the physiological stress (Biswas et al., 2011).

The physical characteristics (age, height, weight, BMI, BSA), work experience, daily working hour and rating of perceived exertions (RPE) by the subjects are presented in the Table-1. Student ' $t$ ' test was performed to compare the physical characteristics and work experience, daily working hour and RPE in that specific job. Results showed high significant difference $(p<0.001$ level) in age, experience, daily working hours and rating of perceived exertions in that specific work but other physical characteristics are not significant. The rating of perceived exertions by the aged (OC) brick carriers $(17.06 \pm 1.39)$ was also much higher $(p<0.001)$ than the younger $(\mathrm{YC})$ ones $(15.13 \pm 0.99$ 
Comparisons of the evaluated cardiac strain parameters were presented in Table 2 . Predicted HRmax , Resting HR and PREC $(\%)$ were significantly $(\mathrm{p}<.001)$ higher in the young carriers, while working HRmax, $\mathrm{SRHB}$, and relative and net $\mathrm{CC}$ were significantly higher in the older group (Table 2). No significant difference was observed for average working HR.

Percentage of reserved $\mathrm{HR}$ for average working HR and working HRmax was lower in older workers than in their younger counterparts (Table 3).

All cardiac parameters were positively correlated with one another except for average working HR with PREC, Relative $\mathrm{CC}$ and Net $\mathrm{CC}$; Working $\mathrm{HR}$ max with PREC and Realtive CC; and SRHB with Relative CC (Table 4). There were significant correlations between age and all cardiac parameters except average working HR with PREC, Relative CC and Net CC; Working HR max with PREC and Realtive $\mathrm{CC}$; and SRHB with Relative CC.

Mean values of predicted HRmax, average working HR and working HRmax did not differ significantly between the two groups (Figure 2).

Figure 3 compares mean HR during 30 min of work and 20 min of partial recovery in the two groups.

In this study, Brick carriers were divided into two groups depending on their age. Age is the most important factor for any type of strenuous activity (Pugh and Wei, 2001; Lusa et al., 1994)) because $\mathrm{HR}_{\max }$ reduces with increasing age (Londeree and Mosechberger, 1982). The assessments of cardiac indices are extremely important for evaluation of cardiac cost as well as physiological work load and study in real situation is limited.

No significance differences of BMI values were observed between the groups and the values (e.g., $19.71 \pm 1.90$ vs. $20.52 \pm 2.55$ $\mathrm{Kg} / \mathrm{m}^{2}$ ) referred to be within the normal limits (Nutritional Trends in India, 1993). It indicated that the personnel did not have any chronic energy deficiency (CED). The duration of work and work experience varied significantly $(\mathrm{p}<0.001)$ between the groups. Rating of perceived exertion shows the significance difference between the groups i.e. older carriers (OC) shows the higher value than their counterparts (table1). So, the older carriers (OC) failed to sustain the workload for long period due to extreme exertion and therefore the number of daily brick carrying were much less than the younger counterpart.

The differences between the cardiac parameters represented (table -2) that cardiac efficiency was much lower among the aged workers (OC) for that specific and identical work load for brick carriers. According to Maritz et al., (1961), the average working heart rate (AWHR) standard for 8 hours industrial jobs should be 105 beats/min with a range of $95-115$ beats/min. But as per Brouha (1967) HR in the industry should not exceed 110 beats/min as cumulative fatigue would likely to ensue beyond this HR level. Later, Saha et al., (1979) proposed that the acceptable workload for sustained physical activity might be considered as $35 \%$ of the maximum aerobic power for Indian male workers, which corresponded to working heart rate of 110 beats/min. The mean average working HR was found to be 127.80 \pm 4.68 beats/min and $130.13 \pm 4.21$ beats/min in the YC and OC respectively. 
Int.J.Curr.Res.Aca.Rev.2016; 4(1): 65-76

Table.1 Physical Characteristics, Work Experience, Daily Working Time and Daily Distance Travelled in 2 Age Groups of Brick Carriers ( $\mathrm{N}=156)$

\begin{tabular}{|c|c|c|c|c|}
\hline Parameters & $\begin{array}{c}\text { Young Carriers }(n=98) \\
(\text { Mean } \pm \text { SD) }\end{array}$ & $\begin{array}{c}\text { Older Carriers }(\mathbf{n}=58) \\
(\text { Mean } \pm \text { SD) }\end{array}$ & $\begin{array}{c}\text { 't' } \\
\text { value }\end{array}$ & $\begin{array}{c}\mathbf{p} \\
\text { Value }\end{array}$ \\
\hline Age (years) & $\begin{array}{c}28.05 \pm 6.04 \\
(18-39) \\
\end{array}$ & $\begin{array}{c}48.85 \pm 4.08 \\
(41-55) \\
\end{array}$ & $-12.76 * * *$ & $<.0001$ \\
\hline Height $(\mathrm{cm})$ & $\begin{array}{c}160.1 \pm 6.54 \\
(149-176)\end{array}$ & $\begin{array}{c}160.3 \pm 4.09 \\
(153-169)\end{array}$ & -0.12 & 0.908393 \\
\hline Weight $(\mathrm{kg})$ & $\begin{array}{c}50.4 \pm 4.08 \\
(44-59)\end{array}$ & $\begin{array}{c}52.6 \pm 5.59 \\
(41-65)\end{array}$ & -1.42 & 0.164337 \\
\hline Body surface area $\left(\mathrm{m}^{2}\right)$ & $\begin{array}{c}1.56 \pm 0.08 \\
(1.45-1.77) \\
\end{array}$ & $\begin{array}{c}1.59 \pm 0.07 \\
(1.44-1.74) \\
\end{array}$ & -1.15 & 0.257987 \\
\hline $\begin{array}{c}\text { Body mass index } \\
\left(\mathrm{kg} / \mathrm{m}^{2}\right)\end{array}$ & $\begin{array}{c}19.71 \pm 1.90 \\
(16.80-23.93) \\
\end{array}$ & $\begin{array}{c}20.53 \pm 2.55 \\
(15.62-26.7) \\
\end{array}$ & -1.15 & 0.259351 \\
\hline $\begin{array}{c}\text { Work } \\
\text { experience(years) }\end{array}$ & $\begin{array}{c}10.3 \pm 3.89 \\
(3-20) \\
\end{array}$ & $\begin{array}{c}24.25 \pm 8.73 \\
(10-38) \\
\end{array}$ & $-6.52 * * *$ & $<.0001$ \\
\hline Daily working time (h) & $\begin{array}{c}7.9 \pm 0.71 \\
(7-9)\end{array}$ & $\begin{array}{c}6.3 \pm 0.732 \\
(5-7)\end{array}$ & $6.97 * * *$ & $<.0001$ \\
\hline RPE Rating & $\begin{array}{c}15.13 \pm 0.99 \\
(13-17)\end{array}$ & $\begin{array}{c}17.06 \pm 1.39 \\
(15-19)\end{array}$ & $-4.37 * * *$ & 0.00019 \\
\hline
\end{tabular}

[Notes: Two-tailed unpaired $t$ test significance value $* * * \mathrm{p}<0.001$; Values in parenthesis indicate the ranges; " $\mathrm{S}$ " indicates the significance and NS indicates the not significant; RPE= Rating of perceived exertion]

Table.2 Resting Heart Rate, Predicted Maximal Heart Rate and Cardiac Strain Parameters in 2 Age groups Brick Carriers ( $\mathrm{N}=156)$

\begin{tabular}{|c|c|c|c|c|}
\hline Parameters & $\begin{array}{c}\text { Young Carriers } \\
(\mathrm{n}=98) \\
(\text { Mean } \pm \text { SD })\end{array}$ & $\begin{array}{c}\text { Older Carriers } \\
(n=58) \\
(\text { Mean } \pm \text { SD })\end{array}$ & $\begin{array}{c}\text { 't' } \\
\text { value }\end{array}$ & $\begin{array}{c}\mathbf{p} \\
\text { Value }\end{array}$ \\
\hline $\begin{array}{l}\text { 1. Resting HR } \\
\text { (beats/min) }\end{array}$ & $\begin{array}{c}81.05 \pm 5.48 \\
(70-92)\end{array}$ & $\begin{array}{c}71.6 \pm 10.21 \\
(60-88)\end{array}$ & $3.65^{* *}$ & 0.001034 \\
\hline $\begin{array}{l}\text { 2. Predicted } \\
\mathrm{HR}_{\max }(\text { beats } / \mathrm{min})\end{array}$ & $\begin{array}{c}186.36 \pm 4.29 \\
(178.57-193.50)\end{array}$ & $\begin{array}{c}171.57 \pm 2.90 \\
(167.19-177.14)\end{array}$ & $12.76 * * *$ & $<.0001$ \\
\hline $\begin{array}{l}\text { 3. Average Working HR } \\
\text { (beats/min) }\end{array}$ & $\begin{array}{c}127.80 \pm 4.68 \\
(120-133.33)\end{array}$ & $\begin{array}{c}130.13 \pm 4.21 \\
(122.25-136.18)\end{array}$ & -1.66 & 0.105146 \\
\hline $\begin{array}{l}\text { 4. Working } \\
\mathrm{HR}_{\max }(\text { beats } / \mathrm{min})\end{array}$ & $\begin{array}{c}142.55 \pm 5.63 \\
(132-149)\end{array}$ & $\begin{array}{c}147.5 \pm 3.35 \\
(142-152)\end{array}$ & $-3.38 * *$ & 0.001983 \\
\hline 5. SRHB & $\begin{array}{c}2069.45 \pm 44.21 \\
(2012-2171)\end{array}$ & $\begin{array}{l}2258 \pm 87.31 \\
(2156-2411)\end{array}$ & $-8.62 * * *$ & $<.0001$ \\
\hline 6. PREC (\%) & $\begin{array}{l}88.40 \pm 10.00 \\
(70.58-100)\end{array}$ & $\begin{array}{c}62.84 \pm 10.98 \\
(44.11-79.17)\end{array}$ & $7.7 * * *$ & $<.0001$ \\
\hline 7. Relative CC (\%) & $\begin{array}{c}55.38 \pm 3.94 \\
(49.18-61.61)\end{array}$ & $\begin{array}{c}59.29 \pm 6.04 \\
(46.09-67.9)\end{array}$ & $-2.42 *$ & 0.021010 \\
\hline 8. Net CC (beats) & $\begin{array}{c}1019.05 \pm 146.25 \\
(837-1382)\end{array}$ & $\begin{array}{c}1365.7 \pm 113.61 \\
(968-1757)\end{array}$ & $-5.01 * * *$ & $<.0001$ \\
\hline
\end{tabular}

[Notes: Two-tailed unpaired $t$ test significance value ${ }^{*} \mathrm{P}<0.05$, ** $<0.01$, *** $\mathrm{P}<0.001 ; \mathrm{HR}=$ heart rate, $\mathrm{HR}_{\max }=$ working maximal heart rate, SRHB= work strain, sum of recovery heart beat, PREC percentage of recovery, $\mathrm{CC}=$ cardiac cost; Values in parenthesis indicate the ranges; ' $S$ ' indicates the significance and NS indicates the not significance] 
Int.J.Curr.Res.Aca.Rev.2016; 4(1): 65-76

Table.3 Percentage of Reserved Heart Rate (HR) for Average Working HR and Working Maximal HR Calculated From Predicted Maximal HR in 2 Age Groups of Brick Carriers

$(\mathrm{N}=156)$

\begin{tabular}{|c|c|l|l|l|l|}
\hline \multirow{2}{*}{ Subjects } & Predicted HR $_{\max }$ & \multicolumn{2}{|c|}{ Average Working HR } & \multicolumn{2}{|c|}{ Working HR $_{\max }$} \\
\cline { 2 - 6 } & $\begin{array}{l}\text { (Mean } \pm \text { SD) } \\
\text { (beats/min) }\end{array}$ & $\begin{array}{l}\text { (Mean } \pm \text { SD) } \\
\text { (beats/min) }\end{array}$ & $\begin{array}{l}\text { As \% of } \\
\text { reserved HR } \\
\text { From HR }\end{array}$ & $\begin{array}{l}\text { (Mean } \pm \text { SD) } \\
\text { (beats/min) }\end{array}$ & $\begin{array}{l}\text { As \% of } \\
\text { reserved HR } \\
\text { From HR }_{\max }\end{array}$ \\
\hline $\begin{array}{c}\text { Young } \\
\text { Carriers } \\
\text { (n=98) }\end{array}$ & $186.36 \pm 4.29$ & $127.80 \pm 4.68$ & 31.42 & $142.55 \pm 5.63$ & 23.50 \\
\hline $\begin{array}{c}\text { Older } \\
\text { Carriers } \\
\text { (n=58) }\end{array}$ & $171.57 \pm 2.90$ & $130.13 \pm 4.21$ & 24.15 & $147.5 \pm 3.35$ & 14.02 \\
\hline
\end{tabular}

[Notes: $\mathrm{HR}=$ heart rate; $\mathrm{HR}_{\max }=$ maximal $\mathrm{HR}$ ]

Table.4 Coefficients of Correlation Between Parameters of Cardiovascular Load Assessment and Participants' Age $(\mathrm{N}=156)$

\begin{tabular}{|c|c|c|c|c|c|c|c|}
\hline & $\begin{array}{l}\text { Predicted } \\
\text { HR }_{\max }\end{array}$ & $\begin{array}{c}\text { Average } \\
\text { Working } \\
\text { HR }\end{array}$ & $\begin{array}{l}\text { Working } \\
\text { HR }_{\max }\end{array}$ & SRHB & PREC & $\begin{array}{c}\text { Relative } \\
\text { CC }\end{array}$ & Net CC \\
\hline Age & $1 * * *$ & $0.16^{*}$ & $0.42 * * *$ & $0.64 * * *$ & $0.43 * * *$ & $0.11 *$ & $0.44 * * *$ \\
\hline $\begin{array}{l}\text { Predicted } \\
\text { HR }_{\max }\end{array}$ & - & $0.16^{*}$ & $0.42 * * *$ & $0.64 * * *$ & $0.43 * * *$ & $0.11 *$ & $0.44 * * *$ \\
\hline $\begin{array}{l}\text { Average } \\
\text { Working HR }\end{array}$ & & - & $0.62 * * *$ & $0.21 *$ & 0.002 & 0.004 & 0.0365 \\
\hline $\begin{array}{l}\text { Working } \\
\text { HR }_{\max }\end{array}$ & & & - & $0.288 * *$ & 0.0498 & 0.0035 & $0.12 *$ \\
\hline SRHB & & & & - & $0.40 * * *$ & 0.066 & $0.25 * *$ \\
\hline PREC & & & & & - & $0.43 * * *$ & $0.69 * * *$ \\
\hline Relative CC & & & & & & - & $0.63 * * *$ \\
\hline Net CC & & & & & & & \\
\hline
\end{tabular}

[Notes: Significance level $* \mathrm{p}<0.05, * * \mathrm{p}<0.01, * * * \mathrm{p}<0.001 ; \mathrm{HR}=$ heart rate; $\mathrm{HR}_{\max }=$ working maximal $\mathrm{HR}$; $\mathrm{SRHB}=$ work strain, sum of recovery heart rate, $\mathrm{PREC}=$ percentage of recovery, $\mathrm{CC}=$ cardiac cost $]$ 


\section{Int.J.Curr.Res.Aca.Rev.2016; 4(1): 65-76}

Figure.1 A Brick Carrier Carrying Brick; Note: Photo by Santigopal Maity

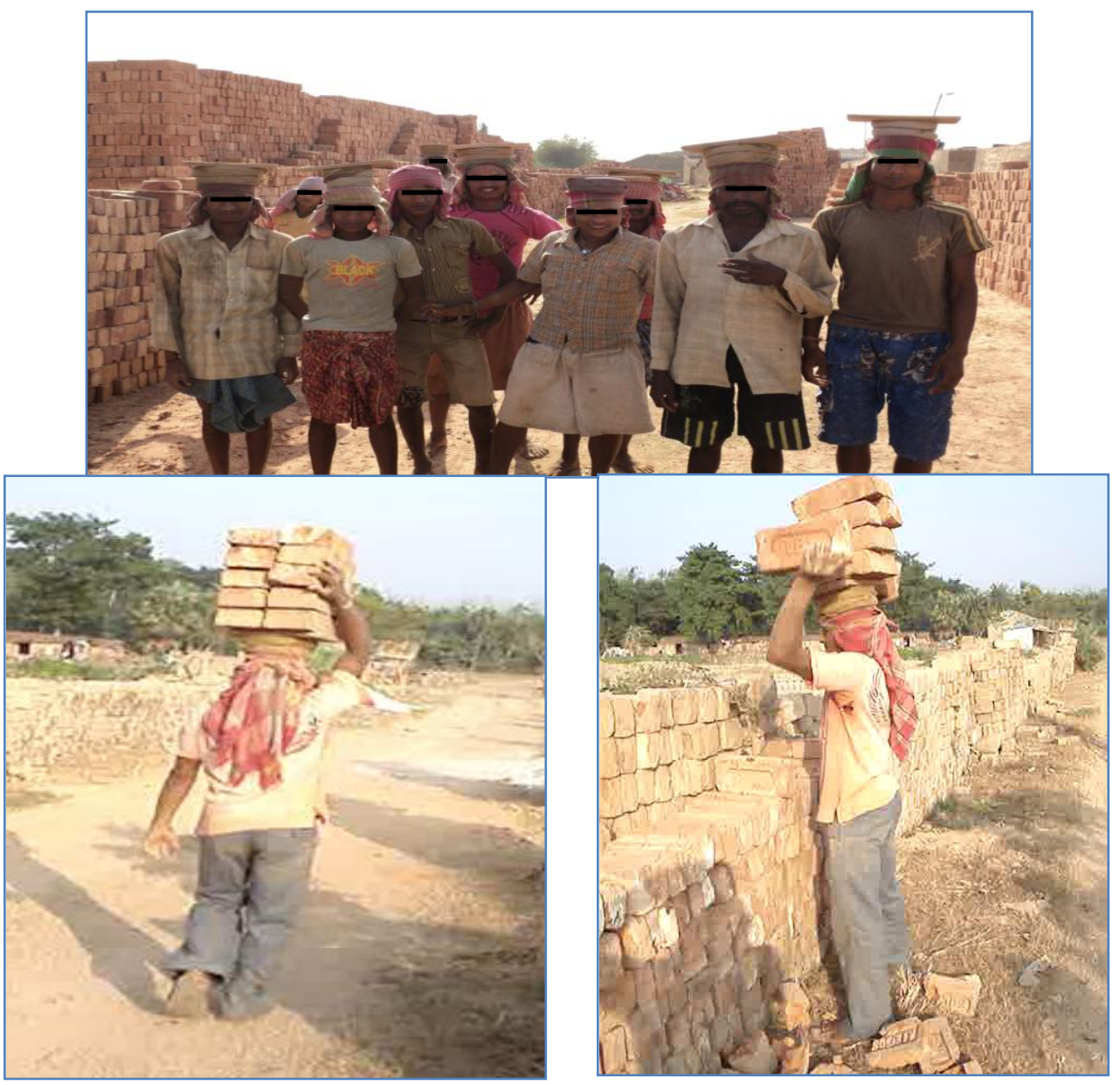

Figure.2 Predicted Maximal Heart Rate (HR), Calculated for Respective Age; Average Working HR and Working Maximal HR in 2 Age Groups Brick Carriers

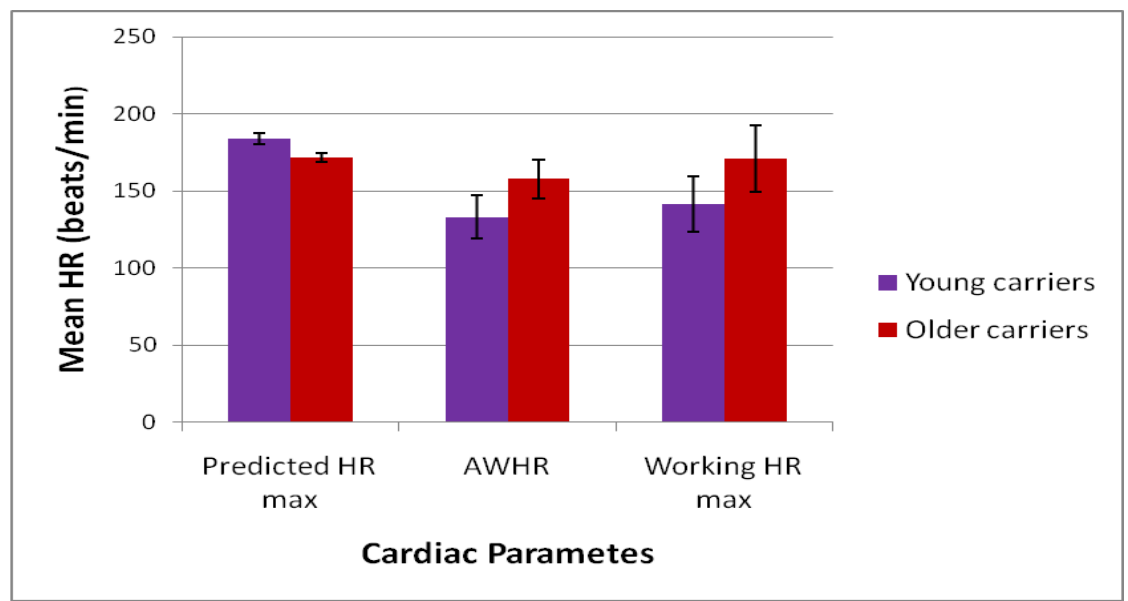

Notes. $\mathrm{HR}=$ heart rate, $\mathrm{HR}_{\max }=$ working maximal heart rate; error bars denote $\mathrm{SD}$ 


\section{Figure.3 Comparison of Mean Working and Partial Recovery Heart Rate (HR) in} 2 Age Groups of Brick Carriers

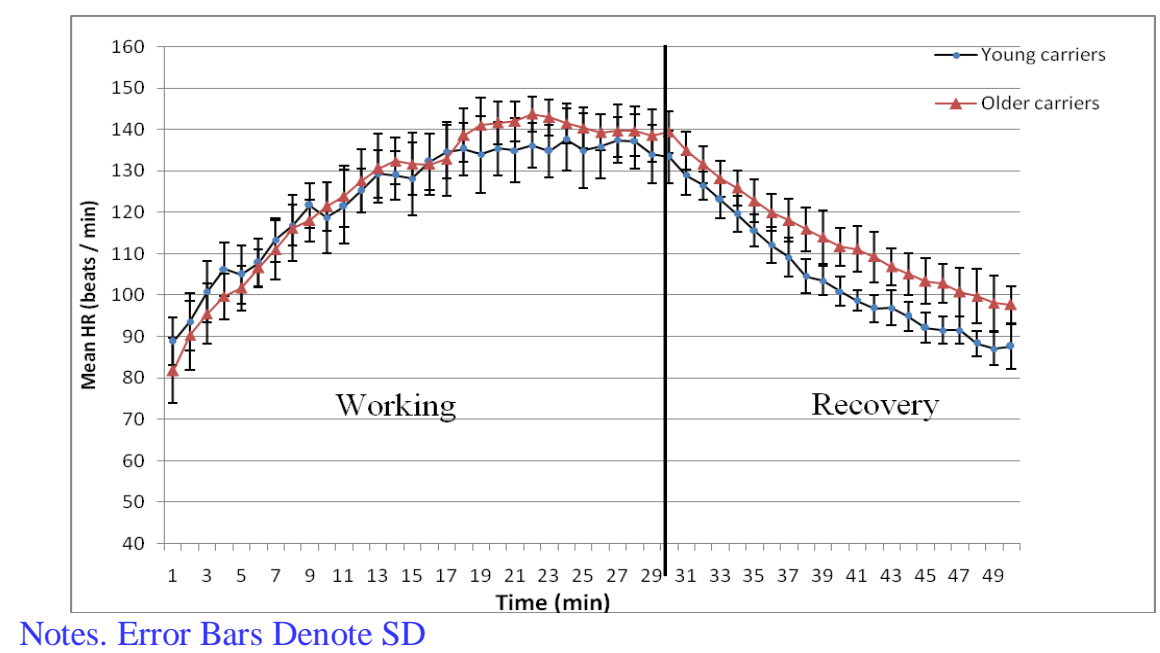

This indicated that the job was heavy in nature as per the guidelines proposed by Astrand and Rodhal (1986). As this work is very stressful and heavy in nature (Drust et al., 2005), it requires extreme muscular force or strength, extreme skilled and also requires more cardiac efficiency. With advancing age, cardiovascular strength decreases (Shephard, 1987) and thus, environmental heat exposure added additional stress to them (Ghosh et al., 2008). The PREC may be considered as a measure of work stress as well as work strain (Pradhan et al., 2008). As the younger carriers had more PREC values (88.40 \pm 10.00 in contrast to $62.84 \pm 10.98$ beats $/ \mathrm{min}$ among the older), it indicated that in order to recover those from exhaustion after work as quick as possible. Therefore, quick recover after work indicate the more of PREC. As the working heart rate was slightly higher among the OC workers (Figure-2), the net $\mathrm{CC}$ and percentage of relative $\mathrm{CC}$ were also higher among the OC workers. It was seen that the brick carriers surpassed the recommended limits of cardiac strain indices like Net CC and \%Relative CC (Brabant et al., 1989), especially with increasing age. It indicated that there was excess physiological work load on the cardiovascular system among the workers with advanced age and therefore more will be the cardiac cost to that group with that specific and same identical workload. where, $\mathrm{WBGT}_{\text {out }}$ as potential confounders, because heat exposure added additional burden to the brick carriers but this was mostly affected to the OC because of less metabolic power (Bugajska et al., 2007; European Committee for Standardization, 2005)

As the net $\mathrm{CC}$ and percentage of relative $\mathrm{CC}$ was much higher among the $\mathrm{OC}$, this might be due to the effect of age on metabolic function of the body and also over reduction of the muscle power. This indicates that there was excessive physiological load on the cardiovascular system among the older carriers (OC).

In the young carriers ( $\mathrm{YC}$ ), the percentage of reserved $\mathrm{HR}$ for average working $\mathrm{HR}$ and working HRmax reached $31.42 \%$ and $23.50 \%$, respectively, compared to $24.15 \%$ and $14.02 \%$ in the older carriers (OC). This indicates that the workload was much heavier for the older participants, probably due to the effect of age on the metabolic 
functions of the body and reduced muscle strength.

The correlation coefficients, which best described the association between cardiac stress indicators and age, reflected this, too. According to Standards No. EN ISO 9886:2004 (European Committee for Standardization, 2004) and No. EN ISO 8996:2004 (European Committee for Standardization, 2004), HR limit in the workplace should not exceed the maximal value for the person reduced by $\sim 20$ beats/min (Bujagska et al, 2007), Figure 3 shows that mean working HR was much higher in the older carriers than in their young counterparts. So, exposure to heat increased the load experienced by the older carriers because of their poorer metabolism (Febbraio et al, 1994; Finn et al, 2003). Consequently, they were unable to work for a long period. This, in turn, reduced the number of carrying bricks, which ultimately affected their earnings.

\section{Conclusion}

Results of this study confirm that brick carrying in the head is a very strenuous job, especially in hot environmental conditions. This requires extreme skilled and extreme muscle strength, which can increase cardiovascular load. Mean values of all parameters in both groups of workers showed that cardiovascular load was very high and increased with age. So, the older participants reduced the number of carrying bricks and lost some of their earnings. Also, all the brick carriers must have to be affected due this extreme environmental condition and excessive physical workload. Global heating due to climate changes will pose an additional threat to this occupation. The workload could be minimized by implementing some ergonomic interventions, e.g., sufficientwork-rest pauses, taking of rehydration solutions between their working period, required some personal protective equipment to protect them from direct sunlight were recommended and the workers were convinced about the work stress.

\section{Acknowledgement}

The authors sincerely thank to all brick field manager and to all the male brick carriers who were constantly in support and have given their precious time and consent to perform this study.

\section{References}

American Conference of Governmental Industrial Hygienists (ACGIH), Threshold limit values for chemical substances and physical agents and biological exposure indices, American Conference of Governmental Industrial Hygienists, Cincinnati, 1992-1993.

Astrand, P.O., Rodhal K. 1986. Textbook of Work Physiology, McGraw-Hill Publication, New York.

Azer, N.Z., McNall, P.E., Leung, H.C. 1972. Effects of Heat Stress on Performance.Ergonomics.15(6): 68191.

Banerjee, S.Sen R.N. 1955. Determination of the surface area of the body of Indians. J Appl Physiol.7: 585-588.

Biswas, R., Samanta, A. 2005. Physiological cost of pond fishing. Indian J Physiol Allied Sci, 59: 58-68.

Biswas, R., Samanta, A. 2006. Assessment of Physiological strain in inland fishing activity.Indian J Occup Environ Med, 10: 19-23.

Biswas, R., Samanta, A., Saha, P. 2011.Cardiac strain of confectionery worker in relation to heat exposure during regular work shift. Indian $J$ Occup Environ Med, 15(3): 120-126.

Brabant,C., Bedard,S.,Mergle, D. 1989. Cardiac strain among women workers 
in an industrial laundry.Ergonomics, 32(6):615-28.

Brouha, L. 1976. Physiology in Industry, Pergamon Press, Oxford, UK.

Bugajska, J., Zużewicz, K., Szmaus-Dybko, M., Konarska, M. 2007. Cardiovascular stress, energy expenditure and subjectiveperceived ratings of fire fighters during typical fire suppression and rescue tasks. International Journal of Occupational Safety and Ergonomics (JOSE). 13(3): 323-332.

Costa, G.,Berti, F., Bett, A. 1989. Physiological cost of apple firming activities. Ergonomics, 20: 281- 286

Coyle, E.F. 2004. Fluid and fuel intake during exercise. $J$ Sports $S c$, 22:39-55.

Das, D. and Das, A. 2004.Statistics in Biology and Psychology, $4^{\text {th }}$ edn, (Academic publishers), Calcutta.

Dey, N.C.,Samanta, A.Saha, R. 2007. Assessment of cardiac strain amongst underground coal carriers - A case study in India. Int $J$ Ind Ergonomics, 37: 489-495.

Drust, B., Rassmussen, P., Mohr, M., Nielsen, B.Nybo, L. 2005.Elevations in core and muscle temperature impairs repeated sprint performance. ActaPhysiol Scand,183: 181-190.

European Committee for Standardization $(\mathrm{CEN})$. Ergonomics of the thermal environment-determination of metabolic rate (Standard No. EN ISO 8996:2004). Brussels, Belgium: CEN: 2004.

European Committee for Standardization (CEN). Evaluation of thermal strain by physiological measurements (Standard No. EN ISO 9886:2005). Brussels, Belgium, CEN: 2005.

European Committee for Standardization (CEN). Ergonomics evaluation of thermal strain by physiological measurements(Standard No. EN ISO
9886:2004).Brussels, Belgium: CEN: 2004.

Febbraio, M.A., Snow, R.J., Stathis, C.G., Hargreaves, M., Carey, M.F. 1994. Effect of heat stress on muscle energy metabolism during exercise. $J$ ApplPhysioly, 77(6): 2827-31.

Finn, P.P., Wood, R.J., Marsden, J.F. 2003. Effect of $30^{\circ} \mathrm{C}$ heat on the anaerobic capacity of heat acclimatized athletes. $J$ Sports Sci Med,2: 158-162.

Ghosh, A.K., Addullah, T.A.T., Kishan, B. 2008. Effect of hot environment on repetitive sprint performance and maximum accumulated $\mathrm{O}_{2}$ deficit of cyclists. International Journal of Sports Science and Engineering, 02 (02): 94100.

Government of India, National Commission for Enterprises in the Unorganised Sector, Social Security for Unorganized Workers-Reports, 2006.

Hancock, P.A., Vasmatzidis, I. 2003. Effects of heat stress on cognitive performance: The current state of knowledge. Int $J$ Hyperthermia, 19(3):355-72.

Londeree, B., Mosechberger, M. 1982. Effect of age and other factors on maximal heart rate. Research Quarterly for Exercise and Sport, $J$ exercise physiol,53(4): 297- 304.

Lusa, S., Louhevaara, V., Kinnunen, K. 1994. Are the job demands on physical work capacity equal for young and aging fire fighters, J Occup Med, 36(1): 70-74.

Maritz, J.S., Morrison, J.F., Peters, J., Strydon, N.B., Wyndham, C.H. 1961. A practical method of estimating an individual's maximum oxygen uptake, Ergonomics. 4:, 97-122.

Nag, P.K, Sen, R.N, Ray, U.S. 1979. Cardio respiratory performance of porters carrying loads on a treadmill. Ergonomics, 22: 897-907. 
Nag, P.K., Dutta, P.1980. Cardiorespiratory efficiency in some agriculture work, ApplErgon, 11: 81-4.

Nutritional Trends in India. 1993. Nutritional Institute of Nutritional, ICMR, New Delhi. P. 33-36.

Parsons, K.C.1993. Human thermal Environments: The effects of Hot, Moderate and cold environments on human health, Comfort and Performance. Taylor and Francis, London. 22: 42-60.

Pitts, G.C., Johnson, R.E., Consolazio, F.C. 1994. Work in the Heat as Affected by Intake of Water, Salt and Glucose. Am J Physiol, 142(2): 253-259.

Pradhan, C.K. 2004 Physiological assessment of cycle rickshaw pullers. Indian Journal of Physiology \& Allied Sciences, 58:113- 118.

Pradhan, C.K., Thakur, S., Mukherjee, A.K., Roychowdhury, A. 2008. Energy expenditure of cycle rickshaw pullers in different places in India, Ergonomics. 51(9): 1407-17.

Pugh, K.G.and Wei, J.Y. 2001. Clinical Implications of Physiological Changes in the Aging Heart, Drugs \& Aging, 18: 263-276.

Ramanamurthy, P.S., Dakhyani, R. 1962. Energy intake and expenditure in stone cutters. Indian J Med Res, 43: 57-61.

Saha, P.N., Datta, S.R., Banerjee, P.K, Narayane, G.G.1979. An acceptable workload for Indian workers, Ergonomics. 22: 1059-1071.

Saha, R., Dey, N.C., Samanta, A., Biswas, R. 2010. Evaluation of Physiological strain of shovellers in underground coal miners in India, Ergonomics, 22: 33-48.

Saha, R., Dey, N.C., Samanta, A., Biswas, R. A. 2007. Comparative study of physiological strain of underground coal miners in India, J Hum Ergol, 36: 1-12.

Sahu, S.,Maity, S.G.,Moitra, S., Sett, M., Haldar, P. 2013. Assessment of Cardiovascular Load During Work in Summer Season of Two Age Groups of Van-Rickshaw Pullers of West Bengal, India, Int J OccupSafErgon (JOSE), 19(4):657-665.

Sensarma, S.K., Samanta, A., Ramanathan, N.L. 1975. Physiological cost of some unskilled building construction jobs, Indian J Occupational Health, 15: 2130.

Sett, M. andSahu, S. 2008. Ergonomic study on female workers in manual brick manufacturing units in West Bengal India, Asian-Pacific Newsletter on Occupational Health and Safety; 15(3): 59-60.

Shephard, R.J. 1987. Physical Activity and Aging, 2nd Ed, Croom Helm Publishing, London.

Snook, S. H. andCiriello, V. M. 1991. The design of manual tasks: revised tables of maximum acceptable weights and forces. Ergonomics, 34: 1197-1213.

Weisell, R.C. 2002. Body mass index as an indicator of obesity. Asia Pac J ClinNutr. 11 (suppl.): S681- S684.

WHO. 1969. Health Factors in working under conditions of heat stress, WHO Technical Report Series, Geneva, 412.

\section{How to cite this article:}

Santi Gopal Maity and Subhashis Sahu. 2016. Assessment of Cardiac Cost of Two Age Groups of Brick Carriers During Summer in Different Unorganized Brick making Sector in West Bengal, India. Int.J.Curr.Res.Aca.Rev. 4(1): 65-76 doi: http://dx.doi.org/10.20546/ijcrar.2016.401.007 